\title{
Picoplankton carbon flux in Chesapeake Bay
}

\author{
Thomas C. Malone ${ }^{1}$, Hugh W. Ducklow ${ }^{1}$, Emily R. Peele ${ }^{2}$, Sharon E. Pike ${ }^{1}$ \\ ${ }^{1}$ University of Maryland System Center for Environmental and Estuarine Studies, Horn Point Environmental Laboratory, \\ Box 775, Cambridge, Maryland 21613, USA \\ ${ }^{2}$ Department of Biology, Western Washington University, Bellingham, Washington 98225, USA
}

\begin{abstract}
Although it is increasingly clear that picoplankton play a major role in the oceanic carbon cycle, relatively little is known concerning the significance of picoplankton in coastal systems subject to significant evironmental variance on tidal to interannual scales. Here we report on seasonal and interannual patterns of variability in the productivity and biomass of phototrophic and heterotrophic picoplankton (P- and H-PICO, respectively) and on the flow of carbon from phytoplankton to H-PICO. Annual cycles in the biomass and productivity of both picoplankton trophic levels exhibit winter-spring minima and summer maxima but do not appear to be directly coupled in terms of carbon flow from $\mathrm{P}$ - to $\mathrm{H}$-PICO. H-PICO exceeds P-PICO during spring when picoplankton productivity is low, and P-PICO exceeds H-PICO during summer when productivity is high. P-PICO productivity and biomass increase rapidly each year to an early summer peak ( $20 \%$ of total phytoplankton productivity on average) immediately following the collapse of the spring diatom bloom. In contrast, H-PICO productivity and the abundance of bacterioplankton (the predominant group of $\mathrm{H}$-PICO) increase slowly to a late summer peak (equivalent to $16 \%$ of phytoplankton productivity on average). Recently released phytoplankton exudates are a major source of dissolved organic carbon with H-PICO taking up an average of $54 \%$ during spring and $83 \%$ during summer Variations in H-PICO are closely coupled to the release of DOC, most of which is produced by phytoplankton $>2 \mathrm{um}$. New nutrient input to the Bay appears to be coupled to H-PICO productivity via increases in the productivity and DOC release of phytoplankton $>2 \mu \mathrm{m}$ in size.
\end{abstract}

\section{INTRODUCTION}

Photosynthetic picoplankton (P-PICO, $<1$ to $3 \mu \mathrm{m}$ ), predominantly cyanobacteria (Waterbury et al. 1979, Johnson \& Sieburth 1979) and prochlorophytes (Chisholm et al. 1988, Olson et al. 1990), play an important role in the carbon cycles of oceans and lakes (cf. Joint 1986, Stockner \& Antia 1986). The proportions of phytoplankton biomass and productivity accounted for by P-PICO typically increase from high to low latitudes (Murphy \& Haugen 1985, Joint 1986) and from eutrophic coastal to oligotrophic oceanic systems (Bienfang \& Takahashi 1983, Li et al. 1983, Platt et al. 1983, Stockner \& Antia 1986, Chavez 1989). In coastal ecosystems, P-PICO has been reported to achieve its annual maximum during summer after the spring bloom in the northern Baltic (Larsson \& Hagström 1982) and Celtic Seas (Joint et al. 1986). Little is known concerning the seasonal variability of picoplankton in temperate estuarine systems subject to seasonal variations in incident radiation and nutrient supply.

On average, P-PICO and photosynthetic nanoplank- ton $(2$ to $20 \mu \mathrm{m})$ account for most photosynthetic biomass in the oceans although episodic and seasonal peaks in biomass are frequently caused by larger, netplankton species (Malone 1980a, b, Joint 1986). This is thought to reflect the predominance of small phytoplankton in stable evironments where phytoplankton biomass is kept in check by grazing and regenerated production is high relative to new production. Episodic inputs of new nutrients associated with vertical mixing and upwelling events often support increases in the biomass of larger phytoplankton (diatoms in particular) and an uncoupling of phytoplankton production and grazing (Walsh 1976, Malone 1980a, b. Sprules \& Munawar 1986, Legendre \& LeFevre 1989). In coastal ecosystems, large accumulations of biomass can result in a shift from metazoan food webs that support high fish yields to microbial food webs that lead to greater decomposition and oxygen depletion (e.g. Swanson \& Sindermann 1979, Bird \& Kalff 1984, Tuttle et al. 1987. Verity 1987).

Free-living heterotrophic bacteria ( $\mathrm{H}-\mathrm{PICO}<1 \mu \mathrm{m}$ in size) appear to exhibit patterns of variability that are 
similar to P-PICO (cf. Ducklow 1983, 1984). Bacterioplankton account for a significant fraction of particulate organic production in most pelagic ecosystems and can dominate the picoplankton in terms of biomass and the flow of carbon (Hagström et al. 1979, Fuhrman \& Azam 1980, 1982, Joiris et al. 1982, Smith et al. 1984, Williams 1984, Ducklow 1986, Fuhrman et al. 1989, Malone \& Ducklow 1990). Both P- and H-PICO are important sources of food for heterotrophic nanoplankton (Haas \& Webb 1979, Fenchel 1982, Sherr \& Sherr 1983, Caron et al. 1985, Goldman et al. 1985, McManus \& Fuhrman 1988 ) and it is generally thought that the microbial food web can be a major source of regenerated nutrients depending on nutrient conditions (Glibert 1982, Azam et al. 1983, Pomeroy 1984, Goldman et al. 1985, Caron et al. 1988, Jumars et al. 1989)

Terrestrially derived dissolved organic carbon (DOC), consisting primarily of humic acids, often accounts for most DOC in estuaries. As indicated by their macromolecular character and by conservative DOC-salinity distributions, humic acids are relatively refractory to microbial decomposition (Mantoura 1981). The principle sources of dissolved organic matter required to support observed levels of bacterioplankton production are believed to be direct release from intact phytoplankton and indirect release through the grazing and excretion activities of zooplankton (Lancelot 1979, Fuhrman et al. 1980. Eppley et al. 1981, Joiris et al. 1982, Larsson \& Hagström 1982, Peterson 1984, Caron et al. 1985, Roman et al. 1988). The relative magnitudes of these pathways has important ecological implications in terms of energy flow and the trophic status of aquatic ecosystems (Bird \& Kalff 1984, Strayer 1988, Fuhrman et al. 1989, Jumars et al. 1989).

The significance of phytoplankton as the source of dissolved organic substrates for H-PICO metabolism has been deduced from large-scale correlations between phytoplankton productivity, release rate of DOC, and H-PICO productivity (Fuhrman et al. 1980 , Bird \& Kalff 1984, Ducklow 1984). Measurements of uptake of recently released phytoplankton exudates by $\mathrm{H}$-PICO indicate that this pathway may support from virtually all to a negligible fraction of $\mathrm{H}$-PICO demand (e.g. Lancelot 1979, Nalewajko et al. 1980, Cole et al. 1982, Joiris et al. 1982, Larsson \& Hagström 1982, Sondergaard et al. 1985). However, DOC release by phytoplankton is less than $10 \%$ of phytoplankton production under most conditions, and estimates of $\mathrm{H}$ PICO demand often exceed this by a factor of 2 to 5 (Sharp 1977, Fuhrman \& Azam 1980, 1982, Sellner 1981, Williams 1981, 1984, Azam et al. 1983, Hagström 1984, Lancelot \& Billen 1985, Malone et al. 1986, Bjørnsen 1988). Recent studies suggest that much if not most of the DOC required to meet $\mathrm{H}$-PICO demand is generated by the feeding and excretory activities of pelagic consumers (Roman et al. 1988, Scavia 1988, Strayer 1988, Jumars et al. 1989).

This contribution is the third in a series that addresses the dynamics of phytoplankton and bacterioplankton in the mainstem of Chesapeake Bay (Malone et al. 1986, 1988). The Bay is a eutrophic, partially stratified estuary subject to large seasonal variability in incident radiation, temperature, and freshwater flow (e.g. Kemp \& Boynton 1984, Schubel \& Pritchard 1986). As shown by Malone et al. $(1986,1988)$, the annual cycles of fresh water flow, new nutrient input and phytoplankton biomass characteristically exhibit spring maxima while the annual cycles of nutrient regeneration and phytoplankton productivity exhibit summer maxima. The productivity and abundance of bacterioplankton are also high during summer, achieving mean levels of about $20 \%$ and $30 \%$ of phytoplankton biomass and productivity, respectively (Malone et al. 1986, Ducklow et al. 1987, Jonas \& Tuttle 1990). Here we report on seasonal and interannual variations in photosynthetic and heterotrophic picoplankton in the context of the annual cycles of phytoplankton biomass and productivity that characterize the mesohaline Bay. The contributions of autotrophic and heterotrophic picoplankton growing in the productive surface waters of the Bay are evaluated in terms of (1) particulate organic carbon production and (2) the flow of organic carbon from phytoplankton to bacterioplankton via recently released phytoplankton exudates.

\section{METHODS}

The experimental design we used is based on a protocol described by Ward (1984) which employs radiotracer and fractionation techniques in an attempt to trace the flow of carbon from the dissolved inorganic pool into phytoplankton size classes and from phytoplankton to DOC and bacterioplankton. Similar experimental approaches have been used by Larsson \& Hagström (1982), Jørgensen et al. (1983), and Søndergaard et al. (1985). As discussed below, the results of such experiments are equivacal and must be interpreted with caution given the complex nature of microbial plankton communities ( $\mathrm{Li}$ 1986). This approach is attractive largely because it is an extension of methodologies that have a long history of use; it has been an important source of information (and debate) concerning the role of microbial food webs in pelagic systems; and it is amenable to field applications requiring frequent measurements. As we hope to show, the approach provides reasonable first order estimates of carbon flows which are useful in elucidating the role of picoplankton in the carbon cycle of Chesapeake Bay.

Experiments were performed at weekly to monthly 
intervals on 29 cruises during 1987 to 1989 as part of an interdisciplinary study of nutrient dynamics in Chesapeake Bay. Water samples were collected from 1 to $2 \mathrm{~m}$ below the surface at Stn 3 of the 'Chop-Pax transect (Fig. 1). This station was selected because of its central location within the mesohaline reach of the Bay where most new nutrient input is assimilated and

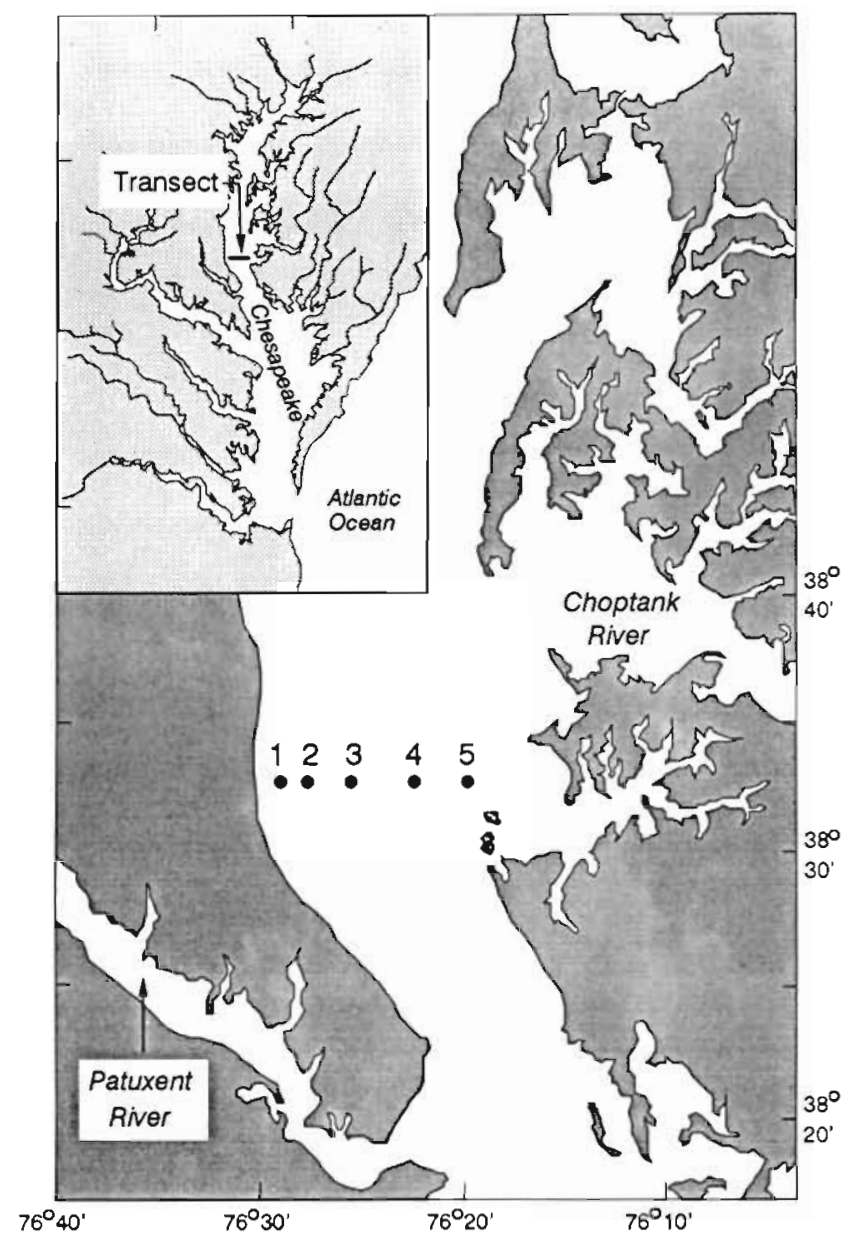

Fig. 1. Chesapeake Bay, USA. Samples were collected at Stn 3 of the Chop-Pax transect

annual production is highest (Boynton et al. 1982, Malone et al. 1988), and it is the site of a time series of measurements of physical and ecological variables initiated in 1984 (Malone et al. 1986)

Each experiment consisted of two $6 \mathrm{~h}$ time courses of ${ }^{14} \mathrm{C}$-uptake into particulate and dissolved organic pools run in parallel at surface water temperature under $70 \%$ sunlight. Whole (unfractionated) water was used for one time course, and water prefractionated through a $1 \mu \mathrm{m}$ Nuclepore filter for the second. Prefractionation was done under low vacuum pressure (<50 $\mathrm{mm} \mathrm{Hg}$ ) using $47 \mathrm{~mm}, 1 \mu \mathrm{m}$ Nuclepore filters. Duplicate whole and prefractionated samples were then dispensed into
$500 \mathrm{ml}$ acid-cleaned, polycarbonate bottles and inoculated with $220 \mu \mathrm{Ci}$ of $\mathrm{NaH}^{14} \mathrm{CO}_{3}$ (Amersham). Subsamples of $50 \mathrm{ml}$ were withdrawn from each bottle at Time $0,1,2,3,4,5$, and $6 \mathrm{~h}$ and sequentially filtered through a $25 \mathrm{~mm}, 1 \mu \mathrm{m}$ Nuclepore filter (whole water only) and a $25 \mathrm{~mm}, 0.45 \mu \mathrm{m}$ Millipore filter (both whole and prefractionated). All filtrations were under low vacuum $(<50 \mathrm{~mm} \mathrm{Hg}$ ) and filtrates were collected for $\mathrm{DO}^{14} \mathrm{C}$ measurements. Samples collected on 1 and $0.45 \mu \mathrm{m}$ filters were acidified with $30 \mu \mathrm{l}$ of glacial acidic acid, exposed to air for $30 \mathrm{~min}$, and placed in $20 \mathrm{ml}$ scintillation vials with $10 \mathrm{ml}$ of Ready-Solv. Filtrates were acidified with $1 \mathrm{~N} \mathrm{HCl}$ to $\mathrm{pH} 1$ and frozen at $-20^{\circ} \mathrm{C}$. Upon returning to the laboratory, the filtrates were thawed, bubbled with filtered air to remove the remaining $\mathrm{H}^{14} \mathrm{CO}_{3}{ }^{-}$, and dispensed ( $1 \mathrm{ml}$ aliquots) into $20 \mathrm{ml}$ scintillation vials with $10 \mathrm{ml}$ of Ready-Solv. ${ }^{14} \mathrm{C}$ activity was measured with an LKB 1212 RackBeta liquid scintillation counter.

Five quantities are measured by this procedure (Fig. 2). Postfractionation time courses yield estimates of (1) photosynthetic carbon incorporation by phytoplankton retained by the $1 \mu \mathrm{m}$ filter, (2) carbon incorporation by phytoplankton and bacterioplankton passed by the 1 um filter, and (3) net DOC accumulation by direct phytoplankton release and by indirect release via the microbial food web. Prefractionation time courses yield rates of (4) carbon incorporation by phy-
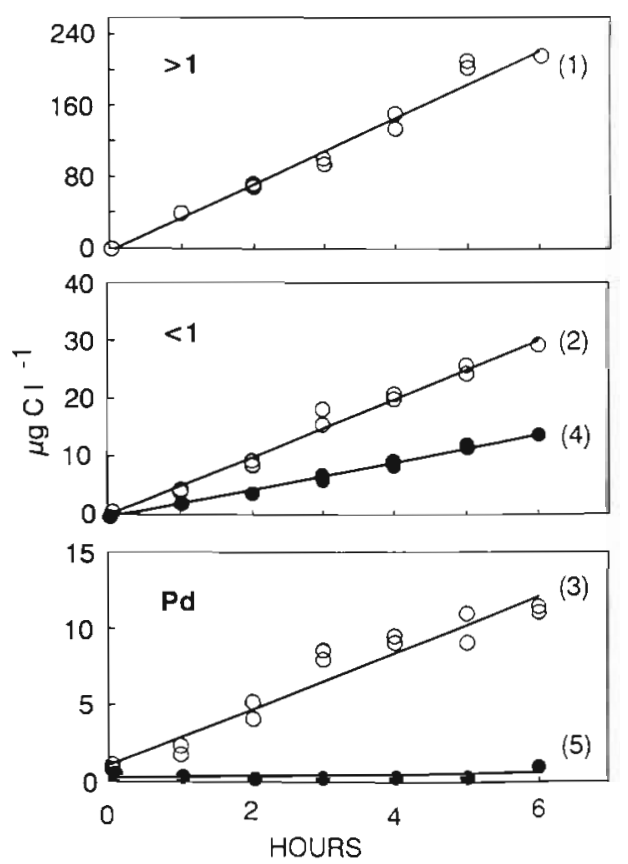

Fig. 2. Representative time courses of ${ }^{14} \mathrm{C}$-incorporation into dissolved $\left(P_{d}\right)$ and particulate $(>1 \mu \mathrm{m}$ and $<1 \mu \mathrm{m})$ pools: time courses 1,2 , and 3 are for post-incubation fractionations; time courses 4 and 5 are for pre-incubation fractionation from an experiment run on 9 June 1988 
toplankton and chemosynthetic bacteria passed by the $1 \mu \mathrm{m}$ filter (assuming a negligible flow of carbon from $\mathrm{P}-\mathrm{PICO}$ to $\mathrm{H}$-PICO) and (5) net DOC release by picoplankton. As recommended by Li (1986), dark bottle 'controls' were not run. Rather, Time $0 \mathrm{~h}$ blanks were subtracted from uptake at each subsequent time point. Although nonlinearities in similar time courses have been reported, particularly for Quantities 3 and 5 (Lancelot 1979), we found uptake into both particulate and dissolved pools to be approximately linear over $6 \mathrm{~h}$ (Table 1). Consequently, rates of carbon flow ( $\mu \mathrm{g} \mathrm{C}$

Table 1. Summary of coefficients of determination $\left(r^{2}\right)$ for 29 time courses of ${ }^{14} \mathrm{C}$ incorporation into post- and pre-fractionated organic pools as shown in Fig. 2

\begin{tabular}{|lccc|}
\hline Fraction & Range & Median & Mean \\
\hline (1) post $>1 \mu \mathrm{m}$ & $0.90-1.00$ & 0.99 & 0.97 \\
(2) post- $<1 \mu \mathrm{m}$ & $0.72-0.99$ & 0.97 & $100 \mathrm{t} 95$ \\
(3) post-DOC & $0.70-0.99$ & 0.93 & 0.92 \\
(4) pre- $<1 \mu \mathrm{m}$ & $0.85-1.00$ & 0.97 & 0.96 \\
\hline
\end{tabular}

$\mathrm{l}^{-1} \mathrm{~h}^{-1}$ ) were calculated from the slope of least square regression of uptake on time (after subtracting Time 0 h blanks) as follows:

$$
\begin{array}{ll}
\mathrm{P}_{\mathrm{p}} & =(1)+(2)+(3), \\
\mathrm{P}_{\mathrm{p}}-\mathrm{PICO} & =(4)+(5), \\
\mathrm{H}_{\mathrm{p}}-\mathrm{PICO} & =(2)-[(4)+(5)], \\
\mathrm{P}_{\mathrm{d}} & =(3)+[(2)-(4)]
\end{array}
$$

where $\mathrm{P}_{\mathrm{p}}=$ total phytoplankton productivity; $\mathrm{P}_{\mathrm{p}}$-PICO = productivity of $\mathrm{P}-\mathrm{PICO} ; \mathrm{H}_{\mathrm{p}}-\mathrm{PICO}=$ uptake of $\mathrm{P}_{\mathrm{d}}$ by $\mathrm{H}-\mathrm{PICO} ;$ and $\mathrm{P}_{\alpha}=$ total rate of $\mathrm{DOC}$ release.

$P_{p}$, which was light saturated at the incubation light level $(70 \%)$, includes $D O C$ release $\left(\mathrm{P}_{\mathrm{d}}\right)$ estimated as the sum of net DOC release and uptake by $\mathrm{H}-\mathrm{PICO} . \mathrm{P}_{\mathrm{p}^{-}}$ PICO is estimated by the sum of particulate uptake and net DOC release in the prefractionated time course. Particulate uptake in the unfractionated time course that is in excess of $\mathrm{P}_{\mathrm{p}}$-PICO is taken as an estimate of $\mathrm{H}_{\mathrm{p}}$-PICO. Note that $\mathrm{P}_{\mathrm{p}}$ and $\mathrm{P}_{\mathrm{p}}$-PICO will be overestimated to the extent that anaplerotic fixation occurred. Anaplerotic fixation by bacteria, the most likely source of chemosynthetic assimilation (Li 1986), cancels out in the calculations of $\mathrm{P}_{\mathrm{d}}$ and $\mathrm{H}_{\mathrm{p}}$-PICO $(2-4)$. As discussed by Li (1986) and others (e.g. Smith et al. 1984), these experiments cannot distinguish between flows of carbon mediated by phytoplankton and microzooplankton when they occur in the same size fraction. Thus, all rates will be underestimated by amounts equivalent to the respective respiratory ${ }^{14} \mathrm{C}$ loss.

Subsamples of whole water were also used to measure chlorophyll a (whole and $<1 \mu \mathrm{m}$ ) and bacterial abundance and productivity. Chlorophyll a (chl) was measured with a Turner Designs fluorometer following extraction with $90 \%$ acetone. The abundance and productivity of bacterioplankton were estimated from direct counts (Hobbie et al. 1977) and rates of incorporation of methyl- ${ }^{3} \mathrm{H}$-thymidine (specific activity $>80 \mathrm{Ci}$ $\mathrm{mmol}^{-1}$, New England Nuclear) into cold TCA-insoluble cell (Fuhrman \& Azam 1980). Stock solutions of ${ }^{3} \mathrm{H}$ thymidine ( $\mathrm{TdR}$ ) were prepared in $0.2 \mu \mathrm{m}$ filtered Milli$\mathrm{Q}$ deionized water and stored at $5^{\circ} \mathrm{C}$ in Teflon bottles. Samples were inoculated with $5 \mathrm{nM} \mathrm{IdR}$ and incubated in the dark at ambient temperature for 15 to 45 min. Zero-time uptake was measured to correct for background levels of label. Samples were filtered at low vacuum pressure $(<200 \mathrm{~mm} \mathrm{Hg}$ ) onto $0.45 \mu \mathrm{m}$ Millipore filters; rinsed 3 times each with cold trichloroacetic acid (TCA), filtered baywater, and $80 \%$ ethanol; and stored dry in scintillation vials. Upon return to the laboratory, filters were prepared for radioassay and counted on an LKB Rack-Beta scintillation counter

\section{RESULTS AND DISCUSSION}

\section{Method evaluation}

The choice of $1 \mu \mathrm{m}$ Nuclepore filters to separate picoplankton was based on the retention characteristics of membrane filters and on the size scale proposed by Sieburth et al. (1978), who recommended the term 'picoplankton' for organisms smaller than $2 \mu \mathrm{m}$. In contrast to screens for which the stated and effective pore sizes are similar, the effective pore size of membrane filters has been shown to differ from the stated pore size (Sheldon \& Sutcliffe 1969). Screens with mesh diameters of $2 \mu \mathrm{m}$ are available, but we have found that $2 \mu \mathrm{m}$ Nitex screens pass phytoplankton cells as large as $20 \mu \mathrm{m}$. Size fractionation experiments with Nuclepore filters show that $2 \mu \mathrm{m}$ Nuclepore filters retain only $50 \%$ of $2 \mu \mathrm{m}$ particles (mean spherical diameter) while $1 \mu \mathrm{m}$ filters retain $70 \%$ (Sheldon 1972). Consequently, organisms that pass a 1 um Nuclepore filter have been functionaily defined as picoplankton (Joint 1986, Li 1986), a practice that we have adopted here.

One concern was that $1 \mu \mathrm{m}$ filters would retain a measurable fraction of the bacteria present in the water column. Using surface samples from the mesohaline Bay, we compared the abundance of bacterioplankton in whole, unfractionated samples with the filtrates of $1 \mu \mathrm{m}$ Nuclepore filters using the AODC technique (Hobbie et al. 1977). The least square regression (model II) of abundance in filtrates on abundance in whole samples gives a slope of 0.96 (SE \pm 0.02$)$ and an intercept of $-0.2(S E \pm 0.3)\left(r^{2}=0.99, n=15\right)$, i.e. $96 \%$ of bacteria were passed by $1 \mu \mathrm{m}$ filters on average. This 
result is consistent with the retention efficiencies reported by Sheldon (1972) for bacterial sized particles.

Size fractionation by filtration is subject to errors related to cell breakage and changes in physiology. We attempted to minimize these potential sources of error by using low vacuum pressure ( $<50 \mathrm{~mm} \mathrm{Hg}$ ) and large diameter filters ( $47 \mathrm{~mm}$ rather than $25 \mathrm{~mm}$ ). Waterbury et al. (1986) found that photosynthesis by Synechococcus spp. was unaffected by gentle prefiltration through $1 \mu \mathrm{m}$ Nuclepore filters (although 20 to $50 \%$ of the cells were retained). An indication that prefiltration had little affect on Chesapeake Bay P-PICO is the strong correlation of $\mathrm{P}_{\mathrm{p}}$-PICO and the chl content of PICO in samples collected over 3 yr during all seasons $(r=0.77$, $\mathrm{n}=27, \mathrm{p}<0.001)$. The intercept of the least square regression (model II) of $\mathrm{P}_{\mathrm{p}}$-PICO on chl-PICO was not significantly different from $0(-1.0, \mathrm{SE}= \pm 2.1)$ and the slope of $6.3(\mathrm{SE}= \pm 1.0)$ approximates the lightsaturated, chlorophyll a specific $\mathrm{P}_{\mathrm{p}}$-PICO reported by Joint \& Pomroy (1986) for the Celtic Sea in summer We also have no direct way to evaluate the effects of cell breakage. However, if this was a significant source of error in our estimates of ${ }^{14} \mathrm{C}$ flow into picoplankton $(<1 \mu \mathrm{m},>0.45 \mu \mathrm{m}), \mathrm{DO}^{14} \mathrm{C}$ would have increased with time in the prefractionation time courses. This was not observed (e.g. Fig. 2, Quantity 5). Although physiological effects of prefractionation and of cell breakage in postfractionation time courses cannot be ruled out, we believe they were minimal.

The flows of carbon into DOC and H-PICO pools will be underestimated to the extent that isotopic equilibrium is not attained (Wiebe \& Smith 1977, Lancelot 1979, Smith 1982). Although an unequivocal demonstration that isotopic equilibrium was achieved in these experiments is not possible, circumstantial evidence indicates that equilibrium was at least approached. First, the time courses were linear, with a resolution of $1 \mathrm{~h}$ over $6 \mathrm{~h}$ (Fig. 2, Table 1). Second, the accumulation of ${ }^{14} \mathrm{C}$ in the DOC and $\mathrm{H}$-PICO pools were a nearly constant fraction of total ${ }^{14} \mathrm{C}$ fixation after the first hour of incubation (Fig. 3). Attainment of equilibrium on these time scales has been observed by a number of workers, particularly in coastal evironments where phytoplankton and bacterial productivity are high (Wiebe \& Smith 1977, Lancelot 1979, Mague et al. 1980, Smith et al. 1986).

$\mathrm{P}_{\mathrm{d}}$ and $\mathrm{H}_{\mathrm{p}}$-PICO will also be underestimated if there is a substantial amount of DOC released by PICO. $\mathrm{DO}^{14} \mathrm{C}$ levels in the prefractionated time courses did not increase with time (Fig. 2) and were consistently a small fraction $(<1$ to $19 \%$, median $=6 \%$, mean $=7 \%)$ of $\mathrm{DO}^{14} \mathrm{C}$ recovered in the postfractionated experiments. Since carbon flow to phytoplankton to dissolved organic carbon to bacterioplankton initially proceeds as a simple catenary sequence, the appearance of ${ }^{14} \mathrm{C}$

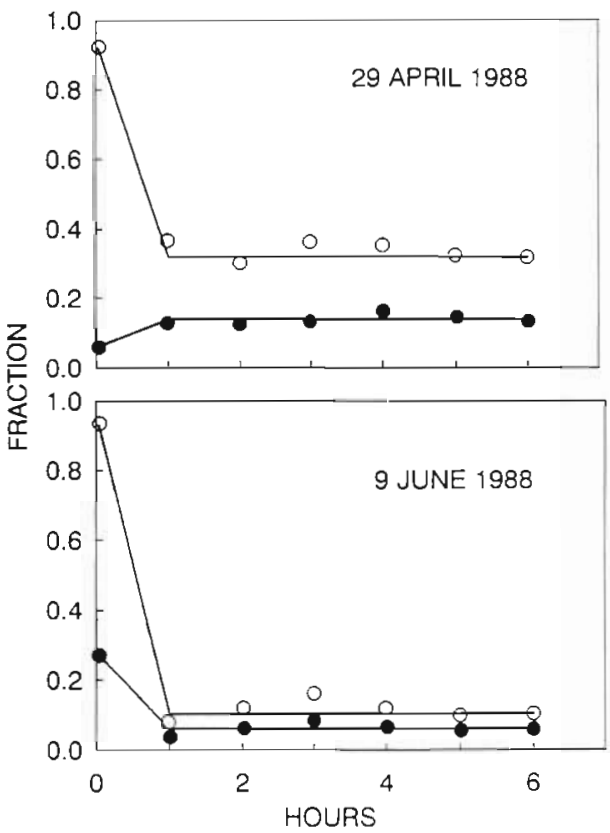

Fig. 3. Representative time courses of the appearance of ${ }^{14} \mathrm{C}$ in the DOC pool (O) and in bacterioplankton ( $)$ normalized to total ${ }^{14} \mathrm{C}$ fixation by phytoplankton; calculated from data shown in Fig. 2

in each pool should exhibit a time lag that is related to the number of transfers required to reach that pool (e.g. Li et al. 1983). Unless all $P_{d}$ was assimilated by $\mathrm{H}$-PICO with little time-lag $(<1$ h) between release and uptake (and the correlation between $\mathrm{P}_{\mathrm{p}}$-PICO and Chl-PICO was fortuitous), these results indicate that P-PICO was a negligible source of $\mathrm{DOC}$ and that ${ }^{14} \mathrm{C}$ uptake in the prefractionated time courses (Quantity 4 in Fig. 2) provided a reasonable estimate of $\mathrm{P}_{\mathrm{p}}$-PICO. Most DOC release was apparently by larger plankton, a conclusion reached by Li et al. (1983) working in the Eastern Tropical Pacific.

Comparisons of $\mathrm{H}_{\mathrm{p}}$-PICO with direct measures of bacterial abundance and ${ }^{3} \mathrm{H}$-thymidine uptake (TdR) suggest that the experimental procedure yields reasonable estimates of carbon flows from phytoplankton to DOC and bacterioplankton. $\mathrm{H}_{\mathrm{p}}$-PICO was significantly correlated with AODC estimates of bacterial abundance $\left(\mathrm{r}^{2}=0.57, \mathrm{p}<0.01\right)$ and with bacterioplankton productivity $\left(\mathrm{r}^{2}=0.78, \mathrm{p}<0.001\right)$ as indicated by $\mathrm{TdR}$ (Fig. 4). The slope of $0.04 \mu \mathrm{g} \mathrm{C} \mathrm{pmol}{ }^{-1}$ is equivalent to commonly used conversion factors used to calculate bacterioplankton productivity from TdR, e.g. $4 \times 10^{18}$ cells mol ${ }^{-1}$ and a conservative estimate of $10 \mathrm{fg} \mathrm{C}^{\mathrm{C}}$ cell $^{-1}$ (Lee \& Fuhrman 1987, Fuhrman et al. 1989). The distribution of data in Fig. 4 suggest that conversion factors may have varied from about 0.02 (low growth efficiency) to 0.08 (high growth efficiency) with high 


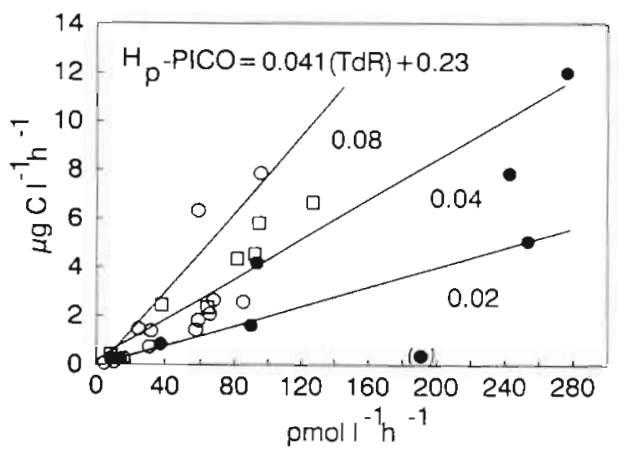

Fig. 4. Comparison of carbon productivity by bacterioplankton calculated from ${ }^{14} \mathrm{C}$ time courses $\left(\mathrm{H}_{\mathrm{p}}\right.$-PICO) and uptake rates of ${ }^{3} \mathrm{H}$-thymidine uptake ( $\mathrm{TdR}$ ): the least-square regression is shown by the middle line; lines with slopes of 0.02 and 0.08 are discussed in the text; the point in brackets was not used in the regression analysis. (ㅁ) 1987 ; (O) 1988; (•) 1989

and low growth efficiencies occurring most frequently during 1987-88 and 1989, respectively.

\section{Seasonal phytoplankton responses to new nutrient input}

In 1987 and 1988, surface phytoplankton biomass and productivity exhibited annual cycles with peaks during spring and summer, respectively (Fig. 5). Chl was highest in May and early June with concentrations of 15 to $20 \mathrm{ug} \mathrm{l}^{-1}$, and $\mathrm{P}_{\mathrm{p}}$ was highest in August with
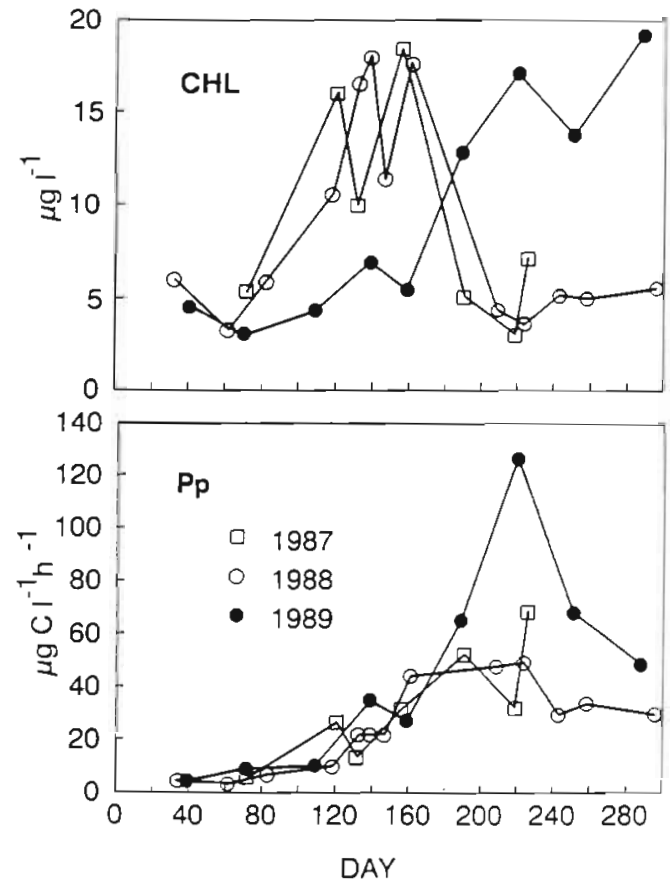

Fig. 5. Surface chlorophyll a concentration (CHL) and phytoplankton productivity $\left(P_{p}\right)$

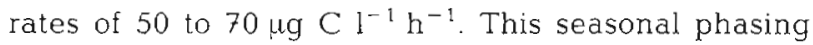
between chl and $P_{p}$ was not observed in 1989 when surface chl exhibited a small spring peak and increased through the summer to an October high of nearly $20 \mu \mathrm{g}$ $\mathrm{I}^{-1}$. Depth-integrated chl during the 1989 spring bloom was also unusually low (Malone unpubl., Sellner pers. comm.). As in previous years, $P_{p}$ peaked in August but at a rate 2 to 3 times the summer peaks of 1987 and 1988.

Annual cycles of water column chl and $\mathrm{P}_{\mathrm{p}}$ are typically out of phase with chl peaking during March to May in response to the seasonal increase in riverborne nutrient input and $P_{p}$ during June to August in response to the seasonal increase in incident radiation and temperature (Malone et al. 1988, Malone 1991). The transition from the spring period of high biomass to the summer period of high productivity occurs as surface temperature exceeds $20^{\circ} \mathrm{C}$ during a $2 \mathrm{wk}$ period in late May-early June and coincides with a change in the distribution of phytoplankton biomass (Malone 1991). During spring, isopleths of chl tend to have a vertical orientation with high chl throughout the water column (in and below the euphotic zone). In contrast, isopleths of chl tend to be horizontally oriented during summer with high chl restricted to the surface layer (within the euphotic zone). The accumulation of biomass during spring is correlated with the volume flow of the Susquehanna River $\left(Q_{\mathrm{f}}\right)$ which usually reaches its annual maximum in March-April (Schubel \& Pritchard 1986 , Malone et al. 1988). In 1989, Qf did not peak until May (U.S. Geological Survey 1990). Given a 1 mo lag between $Q_{\mathrm{f}}$ of the Susquehanma river and downstream volume flow in the surface layer of the mesohaline Bay (Malone et al. 1988, Boicourt 1991), the delivery of new nutrients to the mesohaline Bay would not have occurred until after the transition from spring to summer chl distributions. Thus, the small spring bloom and unusually high summer $\mathrm{P}_{\mathrm{p}}$ observed in 1989 probably reflect the timing of the input of new (riverborne) nutrients with respect to the spring-summer transition and the concurrent seasonal increase of incident radiation and temperature.

These contrasts in annual cycles of chl and $P_{p}$ between the 1989 and the previous 2 years were not observed in the annual cycles of $\mathrm{P}_{\mathrm{p}}$-PICO and ChlPICO (Fig. 6). $P_{p}$-PICO increased rapidly each year as suface temperature exceeded $20^{\circ} \mathrm{C}$ in late May-early June. Little or no lag occurred between Chl-PICO and $\mathrm{P}_{\mathrm{p}}$-PICO which peaked in June-July and July, respectively. As a fraction of $\mathrm{P}_{\mathrm{p}}, \mathrm{P}_{\mathrm{p}}$-PICO was generally less than $2 \%$ from February to May, began to increase rapidly in late May-early June, and reached peaks of about $20 \%$ in June-July. $\mathrm{P}_{\mathrm{p}}$-PICO has been reported to account for similar fractions of summer phytoplankton productivity in temperate continental shelf waters 

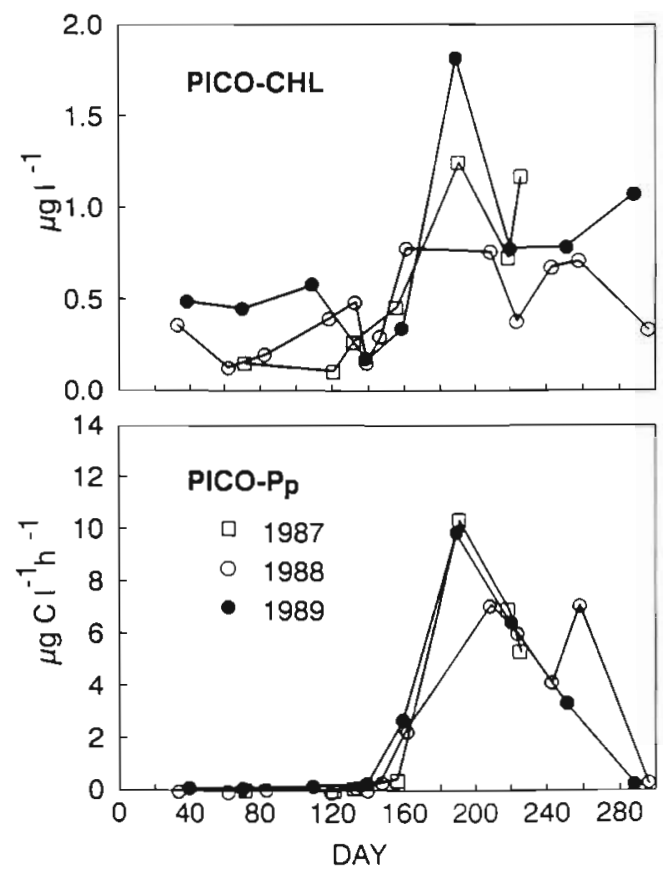

Fig. 6. Surface levels of picoplankton chlorophyll a (PICO$\mathrm{CHL}$ ) and primary productivity (PICO- $\mathrm{P}_{\mathrm{p}}$ )

(Joint \& Pomroy 1983, Douglas 1984, Joint et al. 1986). In Chesapeake Bay, the annual cycle of $\mathrm{P}_{\mathrm{p}}$-PICO showed remarkably little interannual variability. Apparently, the timing of the increase in $\mathrm{P}_{\mathrm{p}}$-PICO and the magnitude of the summer maximum was independent of the timing and magnitude of the spring freshwater flow maximum and associated delivery of new nutrients.

The rapid increase in $\mathrm{P}_{\mathrm{p}}$-PICO reflected an increase in chl-specific $\mathrm{P}_{\mathrm{p}}$-PICO $\left(\mathrm{P}_{\mathrm{p}}{ }^{\mathrm{chl}}\right.$-PICO) from less than $1 \mu \mathrm{g} \mathrm{C}(\mu \mathrm{g} \mathrm{chl})^{-1} \mathrm{~h}^{-1}$ at temperatures less than $20^{\circ} \mathrm{C}$ to rates in excess of $10 \mu \mathrm{g} \mathrm{C}(\mu \mathrm{g} \mathrm{chl})^{-1} \mathrm{~h}^{-1}$ at higher temperatures. $\mathrm{P}_{\mathrm{p}}{ }^{\mathrm{chl}}$-PICO was significantly correlated with temperature $\left(r^{2}=0.80, p<0.001\right)$ as described by the following least-squares regression (model II, with $\pm \mathrm{SE})$ :

$$
\ln \left(\mathrm{P}_{\mathrm{p}}{ }^{\mathrm{chl}}-\mathrm{PICO}\right)=0.19 \pm 0.02(\mathrm{~T})-3.10 \pm 0.84
$$

The exponential constant for this relationship is high compared to values typical of light-saturated photosynthesis and growth of phytoplankton (cf. Malone 1982), perhaps as a consequence of changes in floristic composition. The shift from spring to summer chl distributions coincides with an increase in phytoplankton growth rates from ca $0.1 \mathrm{~d}^{-1}$ to ca $1.0 \mathrm{~d}^{-1}$ (Harding et al. 1986, Malone et al. 1988) and with a rapid change in dominant floristic groups from chain-forming diatoms and large dinoflagellates to small, solitary cyanobacteria and $\mu$-flagellates (Tyler \& Seliger 1978, Van Valkenburg et al. 1978, Malone et al. 1986, Sellner 1987).
Thus, the increase in $\mathrm{P}_{\mathrm{p}}$-PICO not only signals the rapid transition from spring to summer chl distributions, it marks a major change in floristic composition and a shift from the spring period of slow biomass turnover to the summer period of rapid biomass turnover

Phytoplankton DOC release $\left(\mathrm{P}_{\mathrm{d}}\right)$ roughly paralleled variations in $P_{p}$ and was unusually high in late summer 1989 (Fig. 7). Summer rates of 7 to $14 \mu \mathrm{g} \mathrm{Cl}^{-1} \mathrm{~h}^{-1}$ are
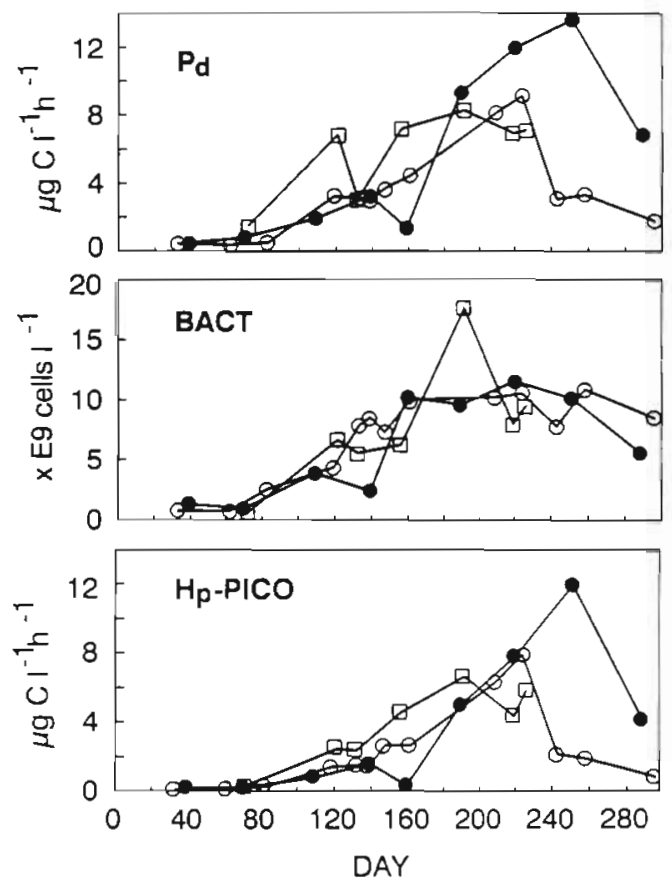

Fig. 7. Release rates of dissolved organic carbon $\left(\mathrm{P}_{\mathrm{d}}\right)$, bacterioplankton cell densities (BACT), and uptake rates of dissolved organic carbon by bacterioplankton $\left(\mathrm{H}_{\mathrm{p}}-\mathrm{PICO}\right)$; symbols as in Fig. 6

also high relative to those reported for other coastal systems (cf. Joint \& Morris 1982). $\mathrm{P}_{\mathrm{d}}$ varied between 5 and $35 \%$ of $\mathrm{P}_{\mathrm{p}}$ with the highest percent release occurring in April and July-August. Contrary to many reports (e.g. Thomas 1971, Berman \& Holm-Hansen 1974, Søndergaard et al. 1985), percent release was not inversely related to productivity. $P_{d}$ was significantly correlated with $\mathrm{P}_{\mathrm{p}}\left(\mathrm{r}^{2}=0.75, \mathrm{p}<0.001\right)$ by the least squares regression (model II, $\pm \mathrm{SE}$ )

$$
P_{d}=0.15 \pm 0.01\left(P_{p}\right)+0.0 \pm 1.7
$$

The slope of the regression gives an estimate of $15 \%$ for the mean fraction of $\mathrm{P}_{\mathrm{p}}$ released as DOC. This is similar to percent release reported for the northern Baltic Sea (Larsson \& Hagström 1982) and in the high end of the range reported for phytoplankton in general (cf. Sharp 1977, Lancelot \& Billen 1985). Similar experiments in the coastal plume of the Chesapeake Bay indicate release rates of $4 \%$ in April and August (Ducklow \& Malone unpubl.). 


\section{Carbon flow to bacterioplankton}

Bacterioplankton abundance and uptake of recently released DOC $\left(\mathrm{H}_{\mathrm{p}}\right.$-PICO) also increased from winter-spring minima to summer maxima but at a more gradual rate and with a later peak than $\mathrm{P}_{\mathrm{p}}$-PICO (Fig. 7). The annual cycle of bacterial abundance and

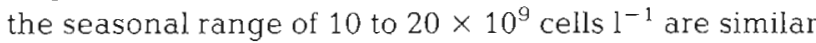
to previous reports for other locations and years in the mesohaline reach of the Bay (Malone et al. 1986, Ducklow et al. 1987, Tuttle et al. 1987, Jonas \& Tuttle 1990) and are high compared to other coastal environments (Williams 1984). Like $\mathrm{P}_{\mathrm{p}}$ and $\mathrm{P}_{\mathrm{d}}, \mathrm{H}_{\mathrm{p}}$-PICO increased to unusually high rates in late summer 1989 and was significantly correlated with $P_{p}\left(r^{2}=0.64, p<0.001\right)$ by the regression

$$
\mathrm{H}_{\mathrm{p}}-\mathrm{PICO}=0.09 \pm 0.01\left(\mathrm{P}_{\mathrm{p}}\right)-0.16 \pm 1.82
$$

As indicated by the slope, an average of $9 \%$ of $P_{p}$ cycled through bacterioplankton via recently released DOC (range of 1 to $18 \%$ ). This is within the range reported for the fraction of phytoplankton production that appears as bacterial production in pelagic systems, and somewhat less than half of that estimated for the mesohaline Bay based on TdR incorporation (Malone et al. 1986, Ducklow et al. 1987, Tuttle et al. 1987, Jonas \& Tuttle 1990). $\mathrm{H}_{\mathrm{p}}$-PICO was better correlated with phytoplankton productivity $>2 u m\left(r^{2}=0.61\right)$ than with $P_{p^{-}}$ PICO $\left(I^{2}=0.39\right)$ reflecting the lag between seasonal peaks in $\mathrm{P}_{\mathrm{p}}$-and $\mathrm{H}_{\mathrm{p}}$-PICO. At its late summer peak, $\mathrm{H}_{\mathrm{p}}$ PICO averaged $16 \%$ of phytoplankton productivity.

As a fraction of $\mathrm{P}_{\mathrm{d}}, \mathrm{H}_{\mathrm{p}}$-PICO was generally between 20 and $60 \%$ at temperatures less than $20^{\circ} \mathrm{C}$ (February to May) and between 50 and $90 \%$ at temperatures greater than $20^{\circ} \mathrm{C}$ (June to September). Similar seasonal ranges have been reported for phytoplankton growing in coastal environments and lakes (e.g. Larsson \& Hagström 1982, Sondergaard et al. 1985). $\mathrm{H}_{\mathrm{p}}$ PICO was significantly correlated with $P_{d}$ during spring $\left(r^{2}=0.85, p<0.001\right)$ and summer $\left(r^{2}=0.95, p<0.001\right)$ by the least squares regressions (model II, $\pm \mathrm{SE}$ )

$$
\begin{aligned}
& \mathrm{H}_{\mathrm{p}}-\mathrm{PICO}=0.54 \pm 0.06\left(\mathrm{P}_{\mathrm{d}}\right)-0.06 \pm 0.57 \text { (spring) } \\
& \mathrm{H}_{\mathrm{p}}-\mathrm{PICO}=0.83 \pm 0.07\left(\mathrm{P}_{\mathrm{d}}\right)-0.83 \pm 0.95 \text { (summer) }
\end{aligned}
$$

The release of DOC by phytoplankton and uptake by bacterioplankton appear to have been closely coupled with $\mathrm{U}_{b}$ averaging $54 \%$ of $\mathrm{P}_{d}$ at temperatures less than $20^{\circ} \mathrm{C}$ (spring) and $83 \%$ at temperatures greater than $20^{\circ} \mathrm{C}$ (summer). Lower percent uptake in spring compared to summer may reflect differences in the molecular composition of released compounds (Lancelot 1984), lower bacterial demand, or differences in the ${ }^{14} \mathrm{C}$ labelling kinetics of the DOC and H-PICO pools (e.g isotopic equilibrium was more closely achieved during summer than spring). In any case, phytoplankton exudates were a significant source of organic substrates for bacterioplankton production, particularly during summer.

Taken together, the proportion of total particulate production accounted for by $\mathrm{P}_{\mathrm{p}^{-}}$and $\mathrm{H}_{\mathrm{p}}$-PICO increased from less than $10 \%$ in late winter to nearly $30 \%$ in summer (Fig. 8). Within the picoplankton, $\mathrm{H}$ PICO accounted for most production during spring when rates were low (Fig. 8). However, $\mathrm{P}_{\mathrm{p}}$-PICO
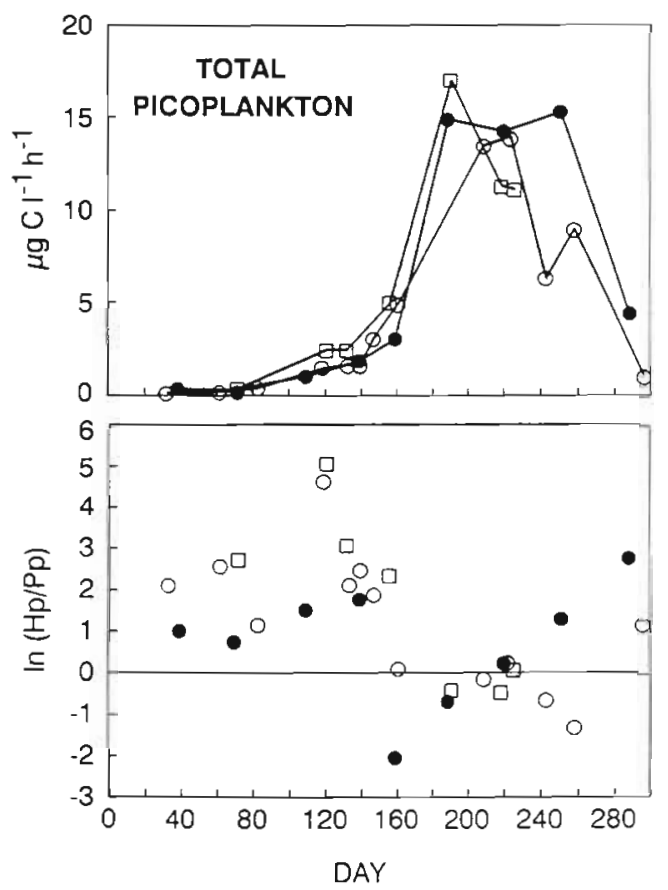

Fig. 8. Picoplankton productivity (phytoplankton + bacterioplankton) and the natural log of the ratio of bacterioplankton to phytoplankton productivity within the picoplankton $\left(\mathrm{H}_{\mathrm{p}}\right)$ $P_{p}$ ): symbols as in Fig. 6

increased relative to $\mathrm{H}_{\mathrm{p}}$-PICO during the transition from spring to summer chl distributions and $\mathrm{H}_{\mathrm{p}}$-PICO fluctuated around $50 \%$ over much of the summer when turnover rates were high. Summer 1989 was again the exception when $\mathrm{H}_{\mathrm{p}}$-PICO increased to unusually high rates and accounted for over $70 \%$ of the carbon flow through the picoplankton.

\section{DOC turnover}

A rough indication of DOC turnover in the surface layer can be gained by comparing phytoplankton release rates with measured concentrations of DOC. DOC in the mesohaline reach of the Bay varies from 1.5 to $6.5 \mathrm{mg} \mathrm{l}^{-1}$, tends to decrease with increasing salinity, and averages about $3.5 \mathrm{mg} \mathrm{I}^{-1}$ with no obvious seasonal trend (Fisher pers. comm.). $\mathrm{H}_{\mathrm{p}}$-PICO averaged 
1.3 and $5.0 \mu \mathrm{g} \mathrm{C} \mathrm{l}^{-1} \mathrm{~h}^{-1}$ during spring and summer, respectively. Using the mean DOC concentration of $3.5 \mathrm{mg} \mathrm{l}^{-1}$, these rates give turnover times of $112 \mathrm{~d}$ during spring and $29 \mathrm{~d}$ during summer.

Dissolved organic compounds range from complex macromolecules (e.g. humic acids) which turn over slowly to simple monomers (e.g. dissolved free amino acids, glycolate) which turn over rapidly (Mantoura 1981, Lancelot 1984, Fuhrman 1990). Although we do not have direct measurements of either of these general pools of organic compounds, measurements of biological oxygen demand (BOD) from $5 \mathrm{~d}$ BOD measurements can be used to roughly estimate the DOC content of the high turnover pool. Jonas \& Tuttle (1990) measured the $5 \mathrm{~d}$ BOD for surface water of the mesohaline reach of Chesapeake Bay after filtering through Gelman A/E glass fiber filters. Mean spring and summer values were $0.27 \mathrm{mg} \mathrm{Cl}^{-1}$ and $0.42 \mathrm{mg}$ $\mathrm{Cl}^{-1}$, respectively. Assuming these to be estimates of the concentration of DOC in the high turnover pool and using $3.5 \mathrm{mg} \mathrm{Cl}^{-1}$ as an estimate of total DOC, these results indicate that about $10 \%$ of the $\mathrm{DOC}$ pool is turning over on a time scale of days or less. Based on mean $\mathrm{H}_{\mathrm{p}}$-PICO, turnover times of this pool are on the order of $9 \mathrm{~d}$ during spring and $3 \mathrm{~d}$ during summer. Assuming that $\mathrm{P}_{\mathrm{d}}=\mathrm{H}_{\mathrm{p}}$-PICO on a time scale of days, turnover times would be on the order of $4 \mathrm{~d}$ during spring and $2 \mathrm{~d}$ during summer (mean $\mathrm{P}_{\mathrm{d}}=2.7$ and $7.0 \mu \mathrm{g} \mathrm{Cl}^{-1} \mathrm{~h}^{-1}$ ). Although $5 \mathrm{~d}$ BOD measurements are at best a rough indication of biologically labile DOC, these calculations indicate that recently released phytoplankton exudates are important in the carbon dynamics of the Bay.

\section{CONCLUSIONS}

Annual cycles of phytoplankton and bacterioplankton productivity are similar, with bacterioplankton productivity averaging $9 \%$ of phytoplankton productivity. The transition from a high biomass, slow turnover system during spring to a lower biomass, high turnover system during summer is marked by a rapid increase $\mathrm{P}_{\mathrm{p}}$-PICO as surface temperature increases above $20^{\circ} \mathrm{C}$. $\mathrm{H}_{\mathrm{p}}$-PICO increases more slowly so that $\mathrm{H}_{\mathrm{p}}$-PICO decreases from greater than $90 \%$ of total picoplankton productivity during spring to about $50 \%$ during summer Thus, carbon flow through the picoplankton, and presumably through the microbial food web as a whole, increases to a summer maximum due to increases in $\mathrm{P}_{\mathrm{p}}$ PICO and, to a lesser extent, in $\mathrm{H}_{p}$-PICO.

The extent to which $\mathrm{P}_{\mathrm{p}}$-PICO dominates carbon flow through the picoplankton can be modified by the timing of the spring freshet. The high summer $P_{p}$ in 1989 appears to be a response to a late freshet which deli- vered nutrients to the mesohaline Bay following the transition from spring to summer plankton communities. The annual cycle of $\mathrm{P}_{\mathrm{p}}$-PICO was unaffected, but $P_{p}$ was higher due to an increase in the productivity of phytoplankton $>2 \mu \mathrm{m}$. DOC uptake by bacterioplankton was also higher during the summer of 1989 , perhaps in response to higher DOC release rates by phytoplankton. Since picoplankton appear to be an insignificant source of DOC, these results suggest that nutrient input associated with the late 1989 freshet stimulated carbon flow through the microbial loop via an increase in DOC release by phytoplankton $>2 \mu \mathrm{m}$ and uptake by bacterioplankton. Bacterioplankton abundance was not higher than in previous years, suggesting that high $\mathrm{H}_{\mathrm{p}}$-PICO reflected higher growth rates or lower growth efficiencies of bacterioplankton. If growth rates were higher, bacterioplankton abundance must have been kept in check by a corresponding increase in grazing losses. The possibility of lower growth efficiency is suggested by the observation that in late summer $1989 \mathrm{H}_{\mathrm{p}}$-PICO was low for a given rate of $\mathrm{TdR}$ incorporation when compared to the previous 2 years, i.e. the rate of $\mathrm{TdR}$ incorporation would be related to carbon productivity by a low conversion factor (Fig. 4).

Although the high productivity characteristic of many estuaries is apparently a consequence of the rates of supply and recycling of nutrients (Nixon 1981, Boynton et al. 1982), the role of bacterioplankton is largely unknown. Inputs of new (allochthonous) nutrients have been shown to stimulate the production of particulate organic matter by both phytoplankton and bacterioplankton on seasonal and annual scales (Boynton et al. 1982, Bird \& Kalff 1984, Hobbie \& Cole 1984). In Chesapeake Bay, seasonal variations in bacterioplankton productivity are not directly related to the input of new nutrients nor to phytoplankton biomass (which peak during spring) but to phytoplankton productivity and DOC release (which peak during summer).

Bacterioplankton take up an average of $54 \%$ and $83 \%$ of $\mathrm{P}_{\mathrm{d}}$ during spring and summer, respectively. Assuming a bacterial growth efficiency of $50 \%$, recently released phytoplankton exudates could account for roughly $25 \%$ (spring) to $40 \%$ (summer) of the carbon metabolized by bacterioplankton. The release of DOC by phytoplankton is a major source of the dissolved organic carbon required to support high bacterioplankton productivity in the Bay, particularly during the summer when phytoplankton productivity is high and river flow is low.

Acknowledgements. We thank S. Kelly for assistance with sampling and measurements. This work was supported by Maryland Sea Grant NA86AA-D-SG006 and by NSF grant BSR-8814272. 


\section{LITERATURE CITED}

Azam, F., Fenchel, T., Field, J. G., Gray, J. S., Meyer-Reil, L. A., Thingstad, F. (1983). The ecological role of watercolumn microbes in the sea. Mar Ecol. Prog. Ser 10: $257-263$

Berman, T., Holm-Hansen, O. (1974). Release of photoassimilated carbon as dissolved organic matter by marine phytoplankton. Mar. Biol. 25: 305-310

Bienfang, P. K., Takahashi, M. (1983). Ultraplankton growth rates in a subtropical ecosystem. Mar. Biol. 76: 213-218

Bird, D. F., Kalff, J. (1984). Empirical relationship between bacterial abundance and chlorophyll concentration in fresh and marine waters. Can. J. Fish. Aquat. Sci. 41: $1015-1023$

Bjornsen, P. K. (1988). Phytoplankton exudation of organic matter: why do healthy cells do it? Limnol. Oceanogr. 33: 151-154

Boicourt, W. C. (1991). Influences of circulation processes on dissolved oxygen in Chesapeake Bay. In: Smith, D., Leffler, M. Mackiernan, G. (eds.) Oxygen dynamics in Chesapeake Bay: a synthesis of recent research. University of Maryland Sea Grant College Publ, College Park (in press)

Boynton, W. R., Kemp, W. R., Keefe, W. M. (1982). A comparative analysis of nutrients and other factors influencing estuarine phytoplankton production. In: Kennedy, V. S. (ed.) Estuarine comparisons. Academic Press, New York, p. $69-90$

Caron, D. A., Goldman, J. L., Anderson, O. K., Dennett, M. R. (1985). Nutrient cycling in a microflagellate food chain. II. Population dynamics and carbon cycling. Mar. Ecol. Prog. Ser. 24: 243-254

Caron, D. A., Goldman, J. L., Dennett, M. R. (1988). Experimental demonstration of the roles of bacteria and bacterivorous protozoa in plankton nutrient cycles. Hydrobiologia 159: 27-40

Chavez, F. P. (1989). Size distribution of phytoplankton in the central and eastern tropical Pacific. Global biogeochem. Cycles 3: 27-36

Chisholm, S. W., Olson, R. J., Zettler, E. R., Goericke, R., Waterbury, J. B. (1988). A novel free-living prochlorophyte abundant in the oceanic euphotic zone. Nature, Lond. 334 : 340-343

Cole, J. J., Likens, G. E., Strayer, D. L. (1982). Photosynthetically produced dissolved organic carbon: an important source for planktonic bacteria. Limnol. Oceanogr. 27 : 1080-1090

Douglas, D. J. (1984). Microautoradiography-based enumeration of photosynthetic picoplankton with estimates of carbon-specific growth rates. Mar Ecol. Prog. Ser. 14. $223-228$

Ducklow, H. W. (1983). The production and fate of bacteria in the ocean. BioScience 33: 494-501

Ducklow, H. W. (1984). Geographical ecology of marıne bacteria: bacteriological and physical variability at the mesoscale. In: Klug, M. J., Reddy, C. A. (eds.) Current perspectives in microbial ecology. Am. Soc. Microbiol., Washington, D.C., p. 22-32

Ducklow, H. W. (1986). Bacterial biomass in warm core Gulf Stream ring 82B: Mesoscale distributions, temporal changes, and production. Deep Sea Res. 33: 1789-1812

Ducklow, H. W., Peele, E. R. Hill, S. M., Quinby, H. L. (1987). Fluxes of carbon, nitrogen and oxygen through estuarine bacterioplankton. In: Lynch, M. P., Krome, E. C. (eds.) Perspectives on research in the Chesapeake Bay. Chesapeake Research Consortium Publ., Gloucester Point, Virginia, p. 511-523
Eppley, R. W., Horrigan, S. G., Fuhrman, J. A., Brooks, E. R., Price, C. C., Sellner, K. (1981). Origins of dissolved organic matter in southern California coastal waters: experiments on the role of zooplankton. Mar. Ecol. Prog. Ser. 6: 149-159

Fenchel, T. (1982). Ecology of heterotrophic microflagellates. II. Bioenergetics and growth. Mar. Ecol. Prog. Ser. 8: $225-231$

Fuhrman, J. A. (1990). Dissolved free amino acid cycling in an estuarine outflow plume. Mar. Ecol. Prog. Ser. 66: $197-203$

Fuhrman, J. A., Ammerman, J. W., Azam, F. (1980). Bacterioplankton in the coastal euphotic zone: distribution, activity, and possible relationships with phytoplankton. Mar. Biol. 60: 201-207

Fuhrman, J. A., Azam, F. (1980). Bacterioplankton secondary production estimates for coastal waters of British Columbia, Antarctica, and Southern California. Appl environ Microbiol. 39: 1085-1095

Fuhrman, J. A., Azam, F. (1982). Thymidine incorporation as a measure of heterotrophic bacterioplankton production in marine surface waters: evaluation and field results. Mar. Biol. 66: 109-120

Fuhrman, J. A., Steeter, T D., Carlson, C. A., Proctor, L. M. (1989). Dominance of bacterial biomass in the Sargasso Sea and its ecological implications. Mar Ecol. Prog. Ser. 57: $207-217$

Glibert, P. M. (1982). Regional studies of daily, seasonal and size fraction variability in ammonium remineralization. Mar Biol. 70: 209-222

Goldman, J. C., Caron, D. A., Anderson, O. K., Dennett, M. R. (1985). Nutrient cycling in a microflagellate food chain. I. Nitrogen dynamics. Mar. Ecol. Prog. Ser. 24: 231-242

Haas, L. W., Webb, K. L. (1979). Nutritional mode of several non-pigmented microflagellates from the York River Estuary, Virginia. J. exp. mar. Biol. Ecol. 39: 125-134

Hagström, A. (1984). Aquatic bacteria: measurements and significance of growth. In: Klug, M. J., Reddy, C. A. (eds.) Current perspectives in microbial ecology. American Society for Microbiology, Washington, D.C., p. 495-501

Hagström, A., Larsson, U., Horstedt, P., Normark, S. (1979). Frequency of dividing cells, a new approach to the determination of bacterial growth rates in aquatic environments. Appl environ. Microbiol. 37: 805-812

Harding, L. W., Meeson, B. W., Fisher, T R. (1986). Phytoplankton production in two East Coast estuaries: photosynthesis-light functions and patterns of carbon assimilation in Chesapeake and Delaware Bays. Estuar coast. Shelf Sci. 23: 773-806

Hobbie, J. E. Cole. J. J. (1984). Response of a detrital foodweb to eutrophication. Bull. mar. Sci. 35: 357-363

Hobbie, J. E., Daley, R. J., Jasper, S. (1977). Use of nuclepore filters for counting bacteria by epifluorescence microscopy. Appl. environ. Microbiol. 33: 1225-1228

Johnson, P. W., Sieburth, J. McN (1979). Chroococcoid cyanobacteria in the sea: a ubiquitous and diverse biomass. Limnol. Oceanogr 24: 928-935

Joint, I. R. (1986). Physiological ecology of picoplankton in various oceanographic provinces. In: Platt, T., Li, K. W. (eds.) Photosynthetic picoplankton. Can. Bull. Fish. Aquat. Sci. 214: 287-309

Joint, I. R., Morris, R. J. (1982). The role of bacteria in the turnover of organic matter in the sea. Oceanogr. mar. Biol. A. Rev. 20:65-118

Joint, I. R., Pomroy, A. J. (1983). Production of picoplankton and small nanoplankton in the Celtic Sea. Mar. Biol. 77 $19-27$

Joint, I. R., Pomroy, A. J. (1986). Photosynthetic characteristics 
of nanoplankton and picoplankton from the surface mixed layer. Mar. Biol. 92: 465-474

Joint, I. R., Owens, N. J. P., Pomroy, A. J. (1986). The seasonal production of picoplankton and nanoplankton in the Celtic Sea. Mar Ecol. Prog. Ser. 28: 251-258

Joiris, C., Billen, G., Lancelot, C., Daro, M. H., Mommaerts, J. P., Bertels, A., Bossicart, M. Nijs, J., Hecq, J. H. (1982). A budget of carbon cycling in the Belgian coastal zone: relative roles of zooplankton, bacterioplankton and benthos in the utilization of primary production. Neth. J. Sea Res. 16: 260-275

Jonas, R. B., Tuttle, J. H. (1990). Bacterioplankton and organic carbon dynamics in the lower mesohaline Chesapeake Bay. Appl. environ. Microbiol. 56: 747-757

Jorgensen, N. O. G., Sondergaard, M., Hansen, H. J., Bosselmann, S., Riemann, B. (1983). Diel variation in concentration, assimilation and respiration of dissolved free amino acids in relation to planktonic primary and secondary production in two eutrophic lakes. Hydrobiol. 107: $107-122$

Jumars, P. A., Penry, D. L., Baross, J. A., Perry, M. J., Frost, B. W. (1989). Closing the microbial loop: dissolved carbon pathway to heterotrophic bacteria from incomplete ingestion, digestion and absorption in animals. Deep Sea Res. 36: $493-495$

Kemp, W. M., Boynton, W. R. (1984). Spatial and temporal coupling of nutrient inputs to estuarine primary production: the role of particulate transport and decomposition. Bull. mar Sci. 35: 242-247

Lancelot, C. (1979). Gross excretion rates of natural phytoplankton and heterotrophic uptake of excreted products in the southern North Sea, as determined by short-term kinetics. Mar. Ecol. Prog. Ser 1: 179-186

Lancelot, C. (1984). Extracellular release of small and large molecules by phytoplankton in the southern bight of the North Sea. Estuar coast. Shelf Sci. 18: 65-77

Lancelot, C., Billen, G. (1985). Carbon-nitrogen relationships in nutrient metabolism of coastal marine ecosystems. Adv. Aquat. Microbiol. 3: 263-321

Larsson, U., Hagström, A. (1982). Fractionated phytoplankton primary production, exudate release and bacterial production in a Baltic eutrophication gradient. Mar Biol. 67: $57-70$

Lee, S., Fuhrman, J. A. (1987). Relationships between biovolume and biomass of naturally derived marine bacterioplankton. Appl environ. Microbiol. 53: 1298-1303

Legendre, L., LeFevre, J. (1989). Hydrodynamical singularities as controls of recycled versus export production in the oceans. In: Berger, W H. (ed.) Productivity of the ocean: present and past. Wiley, New York, p. 49-63

Li, W. K. W. (1986). Experimental approaches to field measurements: methods and interpretation. In: Platt, T., Li, W. K. W. (eds.) Photosynthetic picoplankton. Can. Bull. Fish. Aquat. Sci. 214: 251-286

Li, W. K. W., Subba Rao, D. V., Harrison, W. G., Smith, J. C., Cullen, J. J., Irwin, B., Platt, T (1983). Autotrophic picoplankton in the tropical ocean. Science 219:292-295

Mague, T. H., Friberg, E., Hughes, D. J., Morris, I. (1980). Extracellular release of carbon by marine phytoplankton: a physiological approach. Limnol. Oceanogr. 25: 262-279

Malone, T C. (1980a). Size-fractionated primary productivity of marine phytoplankton. In: Falkowski, P. G. (ed.) Primary productivity in the sea. Plenum, New York, p. 301-319

Malone, T C. (1980b). Algal size. In: Morris, I. (ed.) The physiological ecology of phytoplankton. Blackwell, Oxford, p. 433-464

Malone, T C. (1982). Phytoplankton photosynthesis and car- bon-specific growth: light-saturated rates in a nutrientsaturated Environment. Limnol. Oceanogr 27: 226-235

Malone, T. C. (1991). Effects of water column processes on dissolved oxygen: nutrients, phytoplankton and zooplankton. In: Smith, D., Leffler, M., Mackiernan, G. (eds.) Oxygen dynamics in Chesapeake Bay: a synthesis of recent research. University of Maryland Sea Grant College Publ., College Park (in press)

Malone, T C., Crocker, L. H., Pike, S. E., Wendler, B. W. (1988). Influences of river flow in the dynamics of phytoplankton production in a partially stratified estuary. Mar Ecol. Prog. Ser 48: 235-249

Malone, T C.. Ducklow, H. W (1990). Microbial biomass in the coastal plume of Chesapeake Bay: phytoplanktonbacterioplankton relationships. Limnol. Oceanogr 35: 296-312

Malone, T. C., Kemp, W. M., Ducklow, H. W., Boynton, W R., Tuttle, J. H., Jonas, R. B. (1986). Lateral variation in the production and fate of phytoplankton in a partially stratified estuary. Mar. Ecol. Prog. Ser. 32: 149-160

Mantoura, R. F. C. (1981). Dissolved organic constituents in estuaries. In: United Nations, River inputs to ocean systems. Workshop Proc., U.N. Environmental Programme, United Nations, New York, p. 259-265

McManus, G. B., Fuhrman, J. A. (1988). Clearance of bacteriasized particles by natural populations of nanoplankton in the Chesapeake Bay outflow plume. Mar. Ecol. Prog. Ser. 42: 199-206

Murphy, L. S., Haugen, E. M. (1985). The distribution and abundance of phototrophic ultraplankton in the North Atlantic. Limnol. Oceanogr 30:47-58

Nalewajko, C., Lee, K., Fay, P. (1980). Significance of algal extracellular products to bacteria in lakes and cultures. Microb. Ecol. 6: 199-207

Nixon, S. W. (1981). Remineralization and nutrient cycling in coastal marine ecosystems. In. Neilson, B. J., Cronin, L. E. (eds.) Estuaries and nutrients. Humana Press, Clifton, p. 111-138

Olson, R. J., Chisholm, S. W., Zettler, E. R., Altabet, M. A., Dusenberry, J. A. (1990). Spatial and temporal distributions of prochorophyte picoplankton in the North Atlantic Ocean. Deep Sea Res. 37: 1033-1051

Peterson, B. J. (1984). Synthesis of carbon stocks and flows in the open ocean mixed layer. In: Hobbie, J. E., Williams, P. J. LeB. (eds.) Heterotrophic activity in the sea. Plenum Press, New York, p. 547-554

Platt, T., Subba Rao, D. V., Irwin, B. (1983). Photosynthesis of picoplankton in the oligotrophic ocean. Nature, Lond 301: $702-704$

Pomeroy, L. R. (1984). Significance of microorganisms in carbon and energy flow in marine ecosystems. In: Klug, M. J., Reddy, C. A. (eds.) Current perspectives in microbial ecology. American Soc. Microbiol., Washington, D.C., p. $405-411$

Roman, M. R., Ducklow, H. W., Fuhrman, J. A., Garside, C., Glibert, P. M., Malone, T C., McManus, G. B. (1988). Production, consumption and nutrient cycling in a laboratory mesocosm. Mar Ecol. Prog. Ser. 42: 39-52

Scavia, D. (1988). On the role of bacteria in secondary production. Limnol. Oceanogr. 33: 1220-1224

Schubel, J. R., Pritchard, D. W. (1986). Responses of upper Chesapeake Bay to variations in discharge of the Susquehanna River Estuaries 9: 236-249

Sellner, K. G. (1981). Primary productivity and the flux of dissolved organic matter in several marine environments. Mar. Biol. 65: 101-112

Sellner, K. G. (1987). Phytoplankton in the Chesapeake Bay: 
role in carbon, oxygen, and nutrient dynamics. In: Majumdar. S. K., Hall, L. W., Austin, H. M. (eds.) Contaminant problems and management of living Chesapeake Bay resources. Pennsylvania Academy of Sciences, Philadelphia, p. 134-157

Sharp, J. H. (1977). Excretion of organic matter by marine phytoplankton: do healthy cells do it? Limnol. Oceanogr 22: $381-399$

Sheldon, R. W. (1972). Size separation of marine seston by membrane and glass-fiber filters. Limnol. Oceanogr 17 $494-498$

Sheldon, R. W. Sutclifte, W. H. (1969). Retention of marine particles by screens and filters. Limnol, Oceanogr. 14: $441-444$

Sherr, B., Sherr, E. (1983). Enumeration of heterotrophic microprotozoa by epifluorescence microscopy. Estuar coast Shelf Sci. 16: 1-7

Sieburth, J McN., Smetacek, V., Lenz, J. (1978). Pelagic ecosystem structure: heterotrophic compartments of the plankton and their relationship to plankton size fractions. Limnol. Oceanogr 23: 1256-1263

Smith, R. E. H. (1982). The estimation of phytoplankton production and excretion by carbon-14. Mar Biol. Lett. 3 325-334

Smith, R. E. H., Geider, R. J., Platt, T (1984). Microplankton productivity in the oligotrophic ocean. Nature, Lond. 311 : 252-254

Smith, R. E. H., Harrison, W. G., Irwin, B., Platt, T (1986). Metabolism and carbon exchange in microplankton of the Grand Banks (Newfoundland). Mar Ecol. Prog. Ser 34: $171-183$

Sondergaard, M., Riemann, B., Jørgensen, N. O. G. (1985) Extracellular organic carbon (EOC) released by phytoplankton and bacterial production. Oikos 45: 323-332

Sprules, W. G., Munawar, M. (1986). Plankton size spectra in relation to ecosystem productivity, size, and perturbation. Can. J. Fish. Aquat. Sci. 43: 1789-1794

Stockner, J. G., Antia, N. J. (1986). Algal picoplankton from marine and freshwater ecosystems: a multidisciplinary perspective. Can. J. Fish. Aquat. Sci. 43: 2472-2503

Strayer, D. (1988). On the limits to secondary production. Limnol. Oceanogr 33: 1217-1220

Swanson, R. L., Sindermann, C. J. (1979). Oxygen depletion and associated benthic mortalities in New York Bight, 1976. NOAA Prof. Pap. 11, Rockville, Maryland, 345 p.

Thomas, J. P. (1971). Release of dissolved organic matter from natural populations of marine phytoplankton. Mar. Biol 11. $311-323$

This article was presented by D. A. Caron, Woods Hole, Massachusetts, USA
Tuttle, J. H., Jonas, R. B., Malone, T. C. (1987). Origin, development and significance of Chesapeake Bay anoxia. In: Majumbar, S. K., Hall, L. W., Austin, H. M. (eds.) Contaminant problems and management of living Chesapeake Bay resources. Pennsylvania Acad. Sci. Philadelphia, p. 442-472

Tyler, M. A. Seliger, H. H. (1978). Annual subsurface transport of a red-tide dinoflagellate to its bloom area: water circulation patterns and organism distributions in the Chesapeake Bay. Limnol. Oceanogr 23: 227-246

U.S. Geological Survey (1990). Water resources data. Maryland and Delaware. Water year 1989. Vol. 1. Atlantic slope basins, Delaware River through Patuxent River. U.S. Geol. Surv. Water-Data Rep. MD-DE-90-1

Van Valkenburg, S. D., Jones, J. K. Heinle, D. R. (1978). A comparison by size classes and volume of detritus versus phytoplankton in Chesapeake Bay. Estuar. coast. mar. Sci. 6: $569-582$

Verity, P. G. (1987). Factors driving changes in the pelagic trophic structure of estuaries, with implications for the Chesapeake Bay. In: Lynch, M. P., Krome, E. C. (eds.) Perspectives on the Chesapeake Bay. Chesapeake Research Consortium Publ. No. 127.35-56

Walsh. J. J. (1976). Herbivory as a factor in patterns of nutrient utilization in the sea. Limnol. Oceanogr. 21: 1-13

Ward, B. B. (1984). Photosynthesis and bacterial utilization of phytoplankton exudates: results from pre- and post-incubation size fractions. Oceanol. Acta 7: 337-343

Waterbury, J. B., Valois, F. W., Franks, D. G. (1986). Biological and ecological characterization of the marine unicellular cyanobacterium Synechococcus. In: Platt, T., Li, W. K. W. (eds.) Photosynthetic picoplankton. Can. Bull. Fish. Aquat. Sci. 214-71-120

Waterbury, J. B., Watson, S. W., Guillard, R. R. L., Brand, L. E. (1979). Wide-spread occurrence of a unicellular, marine, planktonic cyanobacterium. Nature, Lond. 277: 293-294

Wiebe, W J., Smith, D. F. $(1977) .{ }^{14} \mathrm{C}$-labelling of the compounds excreted by phytoplankton for employment as a realistic tracer in secondary productivity measurements. Microb. Ecol. 4: 1-8

Williams, P. J. leB. (1981). Incorporation of microheterotrophic processes into the classical paradigm of the planktonic food web. Kieler Meeresforsch. 5: 1-28

Williams, P. J. leB. (1984). Bacterial production in the marine food chain: the emperor's new suit of clothes? In: Fasham, M. J. R. (ed.) Flows of energy and materials in marine ecosystems: theory and practice. Plenum Press, New York, p. $271-299$

Manuscript first received: February 21, 1991

Revised version accepted: September 24, 1991 